\title{
The morphological adaptation of Lithocodium aggregatum Elliott (calcareous green alga) to cryptic microhabitats (Lower Aptian, Spain): an example of phenotypic plasticity
}

\author{
Felix Schlagintweit - Telm Bover-Arnal
}

\begin{abstract}
Lithocodium aggregatum Elliott is interpreted as a heterotrichale chlorophycean alga with a prostrate and erect system within a well-calcified tissue. Within Lower Aptian coral rubble of the western Maestrat Basin, Spain, it forms thick masses of juxtaposed crusts around the bioclasts. In achieving a rapid and complete encrustation of the available bioclasts, Lithocodium applied several strategies, e.g., filling voids of structured surfaces with a special fabric or forming erect extensions to bridge adjacent substrates. In these deposits, different types of poorly if ever illuminated cryptic microhabitats can be distinguished: (1) existing crypts such as empty shells or structural voids within bioclasts (2) crypts resulting from the complete encrustation of adjacent bioclasts by Lithocodium itself and (3) syndepositionally created crypts, e.g., boreholes produced by lithophagid bivalves. In these cases, Lithocodium developed a poorly calcified structure of large cells with thin microcrystalline walls indicating a high degree of variability (phenotypic plasticity). This cryptic growth stage is interpreted as an adaption to the poorly illuminated crypts (photoadaption) in order to maximize light capture for photosynthesis. The Lower Cretaceous Lithocodium is therefore not per se a cryptoendolithic microorganism, but may show adaptation to develop and survive also in these already existing or newly created niches.
\end{abstract}

F. Schlagintweit $(\square)$

Lerchenauerstr. 167, 80935 Munich, Germany

e-mail: ef.schlagintweit@t-online.de

T. Bover-Arnal

Département de Géosciences, Université de Fribourg,

Chemin du Musée 6, 1700 Fribourg, Switzerland

e-mail: telm.boverarnal@unifr.ch
Keywords Lithocodium aggregatum .

Cryptic microhabitats · Phenotypic plasticity ·

Morphological adaptation · Lower Aptian · Spain

\section{Introduction}

Cryptic habitats are those in which organisms are largely enclosed, including underground burrows, caves under rocks, within the shells of other dead or living organisms, etc. (Invertebrate glossary, http://www.palaeos.com/ Invertebrates/Lists/MetGlossary.html). Cryptoendoliths are organisms that dwell in the rock cavities, including spaces that have been actively produced by boring organisms or endoliths (Golubic et al. 1981). It must be pointed out that there is no general consensus or concrete definition about the usage of the terms "cryptic", "cryptic habitat", or "cryptic zone". Some authors use it when organisms are totally hidden from view, others when they are sheltered to some degree from light, thus including cavity-dwellers (e.g., Kobluk and Lysenko 1987). Generally, cavities and other cryptic habitats provide well-protected, space-limited living spaces for low-light adapted organisms (e.g., Kobluk 1988a, b; Meesters et al. 1991; Richter and Wunsch 1999). From modern and fossil cryptic habitats diverse groups of organisms have been reported and described: brachiopods (e.g., Logan et al. 2007; Zuschin and Mayrhofer 2009), bryozoans (e.g., Kobluk et al. 1988; Pachut et al. 1995), corals (e.g., Kobluk and Lysenko 1987), benthic foraminifera (e.g., Lukeneder and Harzhauser 2003; Guilbault et al. 2005), mollusks (e.g., Kase and Hayami 1992; Yamamoto et al. 2009), polychaetes (e.g., Kobluk 1988a; Bastrop et al. 1998; Reolid and Molina 2010) and sponges (e.g., Reitner and Engeser 1987; Wörheide 1998). In both modern and ancient cryptic habitats, microbialites are also 
well documented (Zankl 1993; Reitner et al. 2000; Allouc and Harmelin 2001). As modern cryptic communities are represented by a high level of soft-bodied organisms, a high general taphonomic information loss is generally assumed for ancient cryptic habitats (Rasmussen and Brett 1985). Besides limited space, especially the low light availability reduces the capability for photosynthetic organisms such as algae. In this context, it is worth mentioning that cryptic habitats are often inhabited by rather small organisms (e.g., Jackson et al. 1971).

Among cryptoendolithic organisms, we find those that preferred such a habitat in order to reduce environmental risks such as grazing pressure, physical disturbance, or more generally competition. Other organisms do not exhibit such a preference but are nonetheless able to survive changing light conditions or if the microhabitat becomes a crypt, e.g., due to incrustations. As a logical consequence, however, in the latter cases, the development of morphological adaptations should be expected, so-called photoadaptation. Generally, such intra-specific morphological adaptations to environmental heterogeneity is called phenotypic plasticity (e.g., Bradshaw 1965; Schlichting and Levin 1984; Schlichting 1986; Lortie and Aarssen 1996; Fuller 2003; Hunt 2004). Some modern scleractinian corals that exhibit the ability to thrive in low light levels for example, may adjust their colony form from massive to more flattened and by increasing the spacing of corallites (e.g., Graus and McIntyre 1982; Kobluk and Lysenko 1987; Crabbe and Smith 2006; Klaus et al. 2007). Morphological photoadaptations in order to maximize light capture are not only known from marine but also terrestrial organisms, e.g., land plants (e.g., Pearcy et al. 2005).

Another example of morphological plasticity as an assumed reaction to reduced light conditions is evidenced from the marine calcareous alga Lithocodium aggregatum Elliott from the Early Aptian of Spain. The purpose of this paper is to describe and document the adaptation of this alga to poorly illuminated cryptic habitats as expression of its phenotypic variability. The generally poor knowledge of the morphological adaptations of fossil calcareous green algae to habitats of reduced light availability highlights these new findings.

\section{Geological setting}

The Lithocodium aggregatum Elliott specimens analyzed come from Lower Aptian coral rubble deposits, which crop out throughout the western Maestrat Basin (Iberian Chain; E Iberia) (Fig. 1). The Maestrat Basin was formed during the Late Jurassic-Early Cretaceous rifting cycle that affected the Iberian plate owing to the opening of the Central and North Atlantic realms (Salas et al. 2010). In the course of this extensional activity, over 4,000-m-thick carbonates and siliciclastics ranging from continental to marine conditions accumulated. Later, during Late Eocene-Early Miocene times the Maestrat Basin was inverted due to the Alpine contraction, thus forming part of the Iberian Chain (Salas and Casas 1993; Salas et al. 2001).

The coral rubble deposits sampled constitute a continuous sub-basin-wide horizon (up to $5 \mathrm{~m}$ thick) generated by several episodes of coral rubble accumulation, which were subsequently encrusted by microorganisms, clearly dominated by Lithocodium aggregatum Elliott (see BoverArnal 2010; Bover-Arnal et al. 2010, 2011; Schlagintweit et al. 2010 for further details). The presence of this encrusted deposit in the western Maestrat Basin (Galve sub-basin) has been also reported by Segonzac and Marin (1972), Vennin and Aurell (2001) and Embry et al. (2010). The encrusted levels lie intercalated within the marls of the Forcall Formation and co-occur with abundant Palorbitolina lenticularis (Blumenbach) and more rarely Praeorbitolina gr. cormyi-wienandsi Schroeder, solitary corals, echinoids, brachiopods, ammonites and nautiloids, which point to relatively deep basinal environments (Bover-Arnal 2010; Bover-Arnal et al. 2010). For a compilation of the accompanying microfossils, see Schlagintweit et al. (2010). Further detailed information on microfacies characteristics and discussion are given in Bover-Arnal (2010). The ammonites date these Lithocodium-bearing strata as the upper part of the Deshayesites weissi biozone (Lower Aptian) (Moreno-Bedmar et al. 2009, 2010).

\section{Methods and sampling}

This study is based on laboratory analyses of 73 centimeter-sized thin-sections containing Lithocodium aggregatum Elliott specimens. The samples were collected from the bottom to the top, at upright-spaced decimetric stretches, in eight different sections along the encrusted coral rubble horizon examined. The sections sampled are located in the Barranco de los Degollados, Loma del Horcajo, Las Cubetas, Cabezo de las Hoyas, Camarillas, Casa Cartujo, Barranco de las Calzadas and Barranco de la Serna sites, and are found in the surrounding areas of the villages of Miravete de la Sierra, Camarillas, Aliaga and Montoro de Mezquita (Teruel Province; Spain) (see Fig. 1).

For the illustration of the general appearance of the Lithocodium-crusts shown in Fig. 2, we also included some photographs from the Late Hauterivian of the central Maestrat Basin (for details see Tomás et al. 2007 and Götz et al. 2005). 


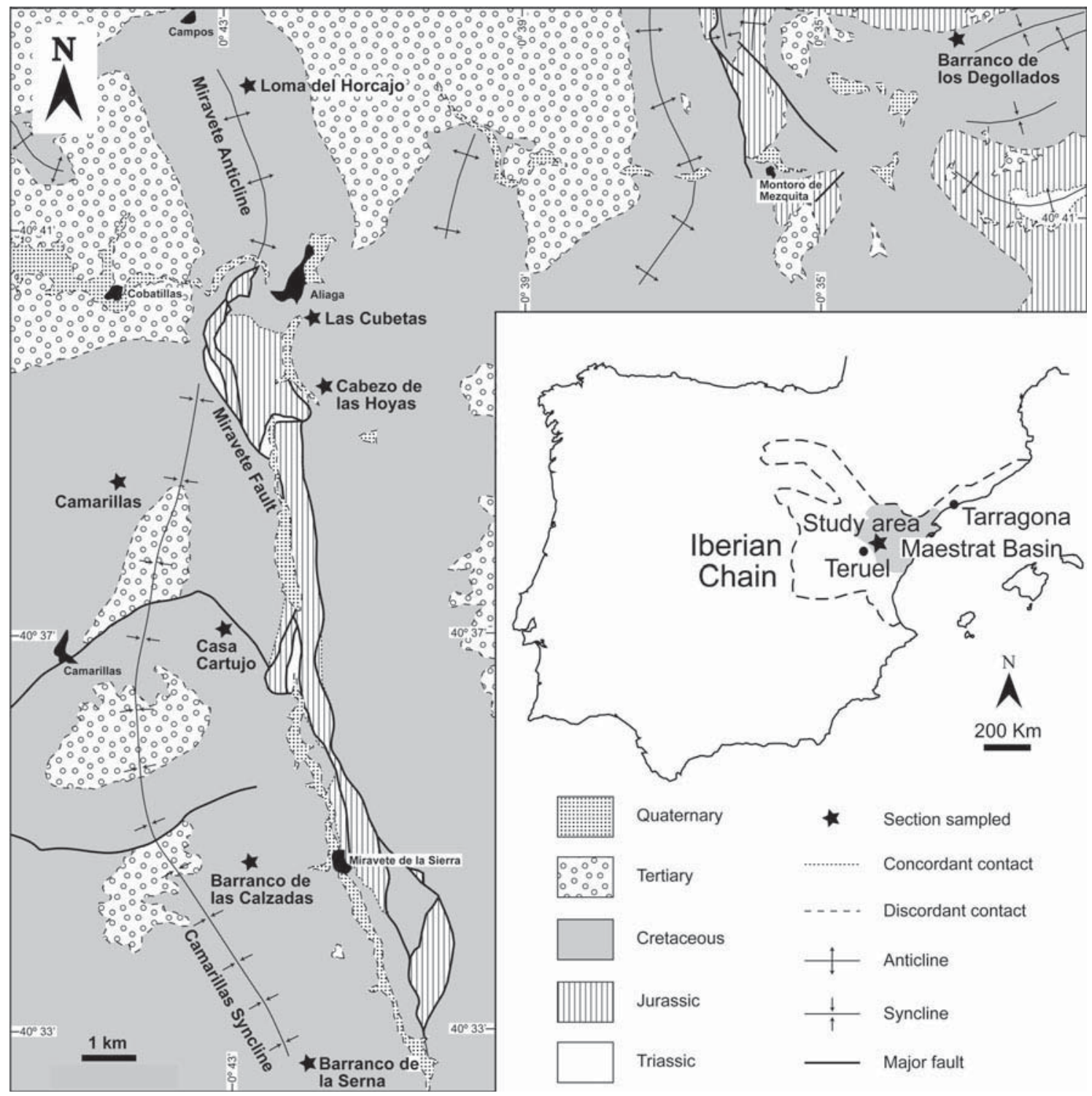

Fig. 1 Location of the sections sampled in the western Maestrat Basin (Iberian Chain, E Iberia). Geological map modified after Canérot et al. (1979) and Gautier (1980)

\section{Results}

General appearance of Lithocodium crusts

Lithocodium aggregatum Elliott has been recently reinterpreted as an ulvophycean calcareous green alga exhibiting a basal prostrate branching system of septate filaments and upright septate filaments that may branch up to several orders (Schlagintweit et al. 2010), a bauplan that represents the highest developed type of filamentous habit (e.g., Sambamurty 2005) (e.g., Fig. 2a). Usually, Lithocodium aggregatum Elliott forms thick masses (thickness highly variable, up to few centimeters) of juxtaposed crusts (individual crust thickness ranges from 0.2 to $0.4 \mathrm{~mm}$ ) upon coral bioclasts ( $\sim 95 \%$ of the order Microsolenina in the Lower Aptian material) and more rarely rudistid fragments or oyster shells (Fig. 2). In very thin crusts, the erect system may be reduced to only one order of short filaments. These thin and poorly calcified crusts never occur directly upon the substrate, but usually form medium to outer layers, and overlie thicker and well-calcified thalli (Fig. 2b). Nevertheless, the poorly calcified crusts can be also missing (Fig. 2f). On the other hand, older layers may exhibit strong micritization of the filament system.

Adaptations to the substrate surface morphology

The basal construction of a first Lithocodium-crust attaching to the substrate depends on the surface structure. On smooth surfaces (e.g., rudist shells), Lithocodium directly 

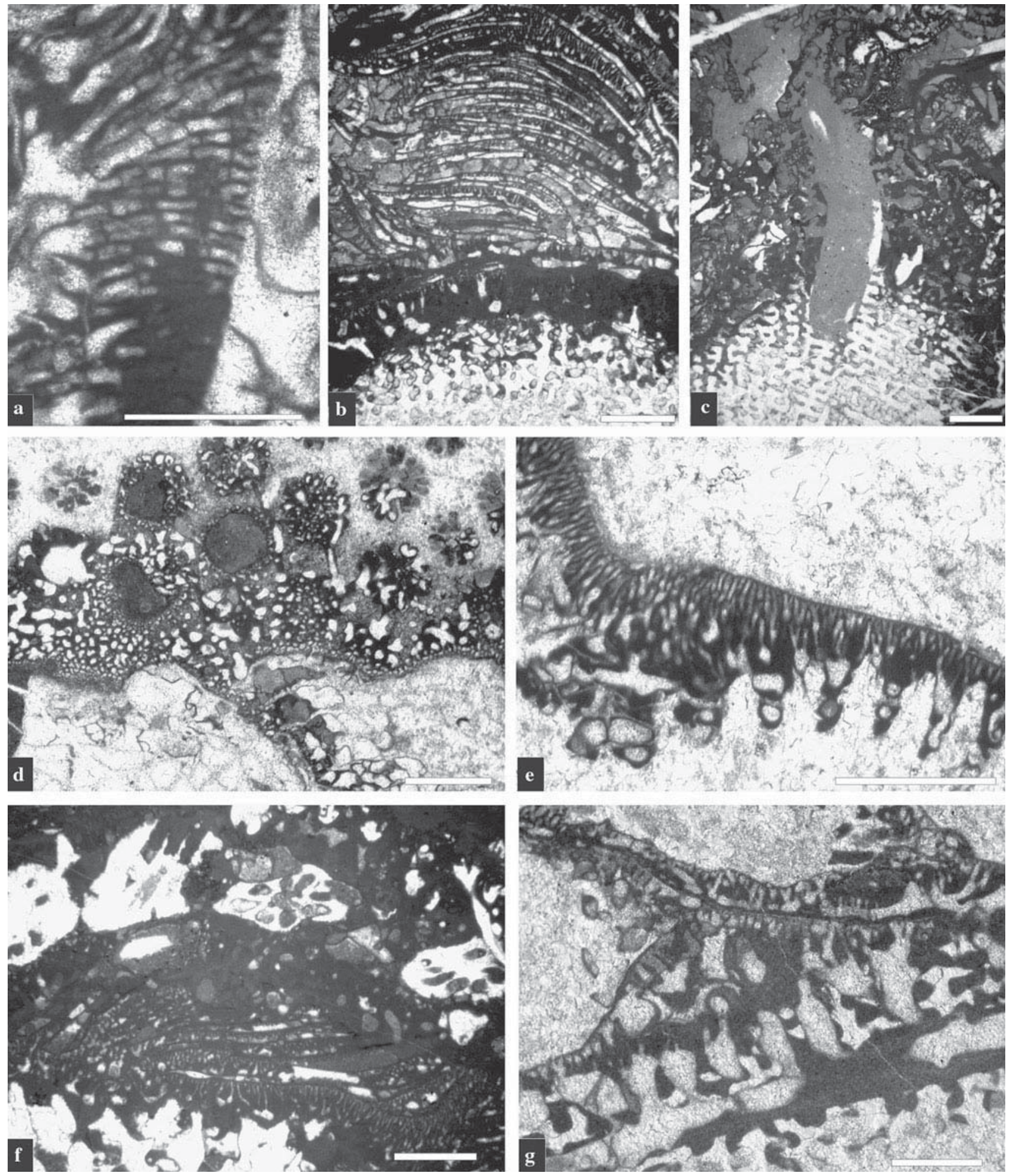

attaches towards the substrate with the prostrate system and a thin basal layer of micrite. In this case, the prostrate filaments successively branch and radiate in growth direction. On fissured or sculptured substrates the tissue of Lithocodium invades into the skeletal voids or fissures.
Substrate surfaces exhibiting rather aligned shallow and narrow furrows between ridges, are occupied by Lithocodium in a way that the prostrate filaments closely attach into the furrows, and there creep in a parallel manner (Fig. 2e). The thicker first order of the erect filaments may 
4 Fig. 2 Crusts of Lithocodium aggregatum Elliott upon coral substrates from the Late Hauterivian $(\mathbf{a}, \mathbf{d}-\mathbf{e}, \mathbf{g})$ of the central Maestrat Basin and the Lower Aptian (b, c, f) of the western Maestrat Basin, Spain. a Heterotrichale thallus organization showing the septate erect filaments branching in several orders, detail from $\mathbf{e}$ (other part of the thin-section). b Mass of various superimposed crusts consisting of a rather thick basal crust and numerous thin and poorly calcified layers in the middle part. Note the invasion of the algal tissue in the structural voids of the coral skeleton. c Macroboring of an unknown organism through Lithocodium crusts and into a coral skeleton. d Colony of a plocoid scleractinian coral overgrown by Lithocodium aggregatum (transverse-oblique sectioned) and downward intrusion into the spaced calices. e Single layer of Lithocodium aggregatum upon sculptured coral surface. Observe how the prostrate filaments (more or less transverse sectioned) are growing into the furrows and how the erect filaments form the crust upon the outer substrate surface. f Crusts of Lithocodium aggregatum upon a sculptured coral surface followed by massive crusts totally enveloping corallites of scleractinian corals. g Lithocodium aggregatum attaching to a microsolenid coral. The algal tissue invaded into the sculptured skeleton and grew laterally completely enclosing the septal elements. Scale bars $1 \mathrm{~mm}$, except $\mathbf{c}, \mathbf{g}=0.5 \mathrm{~mm}$. Thin-sections: a, d-e AV 155b-2a, b CA 3H, c HO 11, f HO 6 V, g AV 122

also be situated in these furrows. Then the crustal part that overlies the skeletal substrate is represented only by the erect system and, depending on the width and depth of the furrows, sometimes only by the last order filaments. In highly internally structured coral skeletons (e.g., order Microsolenina), the tissue of Lithocodium developed as a cellular cryptic fabric may enter more than $1 \mathrm{~mm}$ deep into the porous septal interstices (Fig. 2b, below). In the same way, colonies of plocoid scleractinian corals encrusted by Lithocodium aggregatum display the intrusion of the algal tissue into the spaced calices (Fig. 2d). On the other hand, corallites that came in contact with crusts of Lithocodium aggregatum that were already fixed to the substrate, became totally incorporated by the enveloping algal crusts (Fig. 2f). When Lithocodium aggregatum attached to a coral with rather wide furrows (in comparison to Fig. 2e) a card-house-like cryptic basal stage was developed filling the existing interstices (Fig. 5e). In microsolenid corals, with their special microstructure of perforate septa (e.g., Morycowa and Roniewicz 1995, Fig. 6), Lithocodium aggregatum could invade the marginal zone of the coral skeleton growing between the septa and coating them during continued growth (Fig. 2g).

\section{Adaptations to inter-bioclasts}

A couple of the thin-sections studied are completely formed by an intimate mass between black Lithocodium

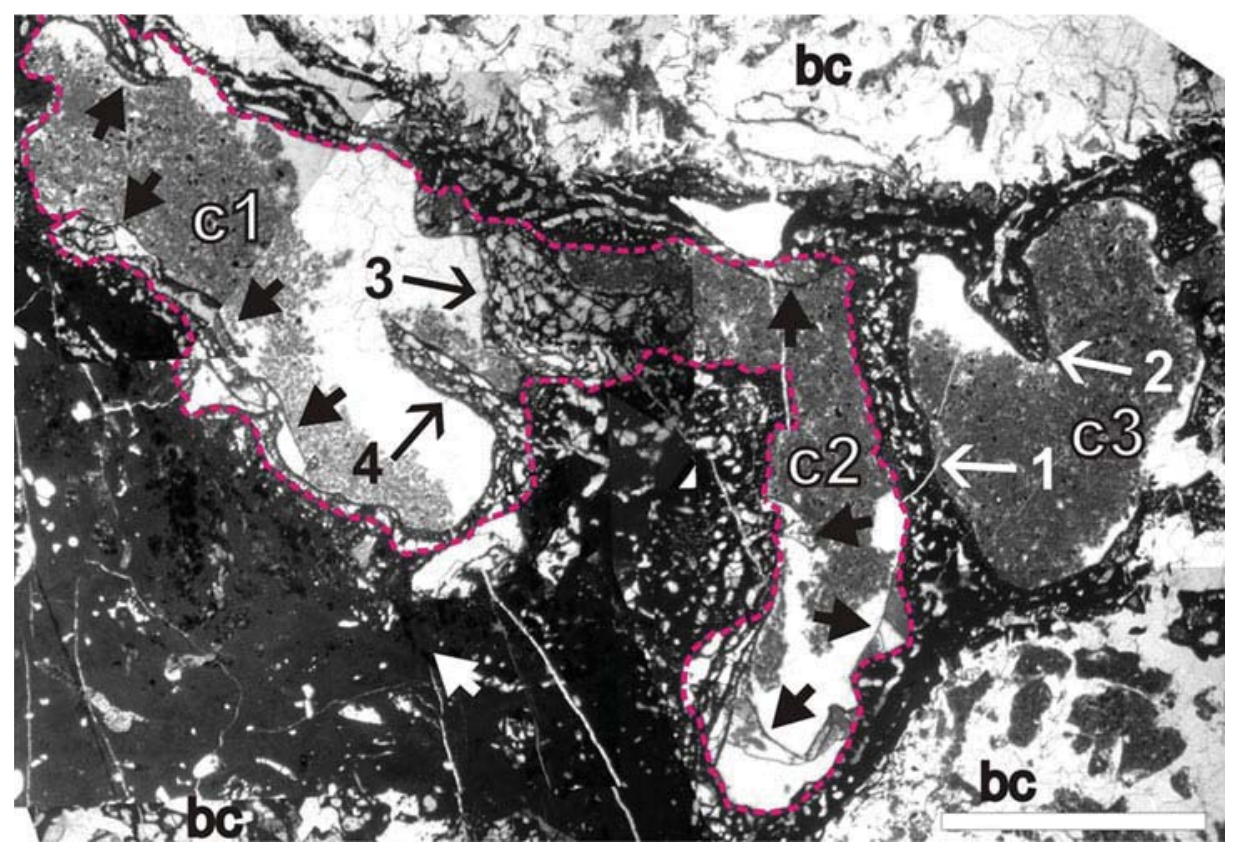

Fig. 3 Microfacies of coral bioclasts $(b c)$ encrusted by Lithocodium aggregatum Elliott, Lower Aptian of the western Maestrat Basin, Spain. Lithocodium-bridges connect adjacent bioclasts (white arrow 1 and black arrow 3) forming three self-made crypts ( $c 1$ to $c 3$ ); incomplete bridges not reaching the other side form protuberances projected into the crypts (white arrow 2, black arrow 4). Crypt 1 and 2 originally formed one larger void that became closed by a bridge build by the cellular meshwork of the cryptic stage of Lithocodium (black arrow 3), thus forming two independent crypts. Note that also the cryptic stage may form incomplete bridges (black arrow 4). Whereas in crypt 3 no cryptic Lithocodium stage occurs for unknown reason (perhaps not completely closed and thus, letting enough light passing into it), these cellular structures developed in the other two crypts (black fat arrows). The boundary between the cryptic and the epilithic growth stage is marked by a dashed red line. The different oriented geopetal fillings in crypt 1 and crypt 3 point to movements during the growth of these structures. Scale bar $5 \mathrm{~mm}$. Thin-section CAL $6 \mathrm{~V}$ 
crusts and coral bioclasts lacking the fine-grained and siliciclastic-influenced matrix. In other examples, where the spaces between the bioclasts are not completely filled with Lithocodium-crusts, it is possible to follow the encrustation history. In these latter cases, the bioclasts show an overall encrustation of Lithocodium, formed by a thick package of superimposed crusts, or by only some layers. Projections of these crusts stretch into the free voids between the bioclasts. Depending on whether they connect two adjacent bioclasts or not, these constructions are here termed "incomplete" and "complete Lithocodium bridges", respectively (Figs. 3, 4). The bridges may consist of both thick-massive and poorly calcified, irregular cellular crust. These constructions build by Lithocodium may result in internal voids or crypts, that in most
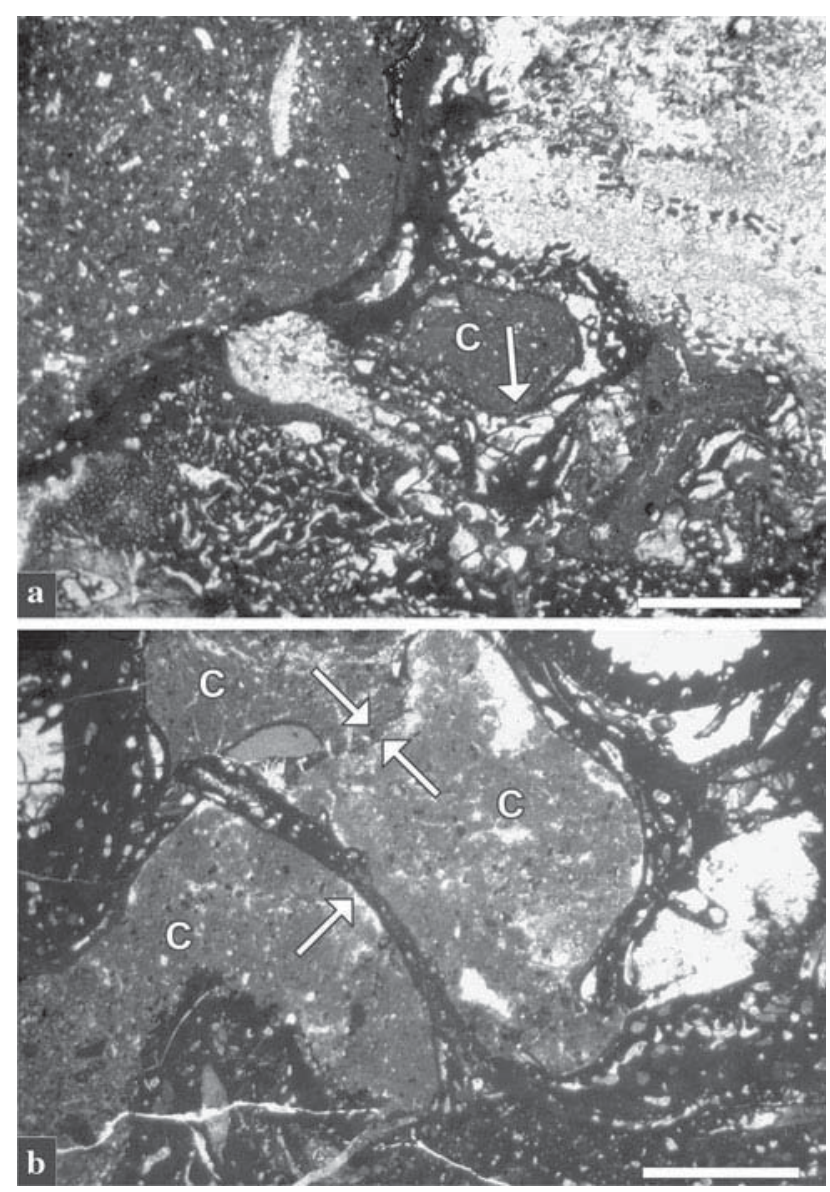

Fig. 4 a, b "Lithocodium bridges" from the Lower Aptian rubble deposits of the western Maestrat Basin, Spain. a Coral bioclasts connected by a crust of Lithocodium aggregatum Elliott, thus creating a crypt or cavity $(c)$ with development of the cryptic growth stage (white arrow). The complete filling of the void with sediment documents that it did not become completely closed from all sides. Sample CAL 2. b "Lithocodium bridges" between already intensely encrusted bioclasts forming crypts $(c)$, more or less completely filled with sediment. The fact that no cryptic growth stage of Lithocodium developed inside the crypt could be an indication that it must have been well enough illuminated. Sample SE 5H. Scale bars $2 \mathrm{~mm}$. Thin-sections: a CAL 2, b SE $5 \mathrm{H}$ cases were not closed by further crust growth but were filled with sediment.

Adaptations to cryptic microhabitats

Lithocodium aggregatum was able to grow into and encrust the side walls of small cavities or crypts. This ability was observed within cavities that already existed prior to the colonization of Lithocodium (e.g., skeletal voids), within more or less synsedimentary crypts such as borings of lithophagid bivalves and last but not least, within crypts resulting from the encrusting way of life of Lithocodium itself (Figs. 5, 6, 7, 8).

\section{Substrate immanent existing crypts}

This type of crypt refers to skeletal voids (e.g., of corals, rudistids or the interior of pelecypod shells), which existed before they became colonized by Lithocodium (Figs. 5a, e, $\mathrm{g}, \mathrm{h} ; 6 \mathrm{~b}, \mathrm{e})$. They can be referred to as primary crypts. When bioclasts were opened to one side, Lithocodium was able to enter and fill the hollow with the basal cellularcryptic stage. At the transition to the exterior the wellcalcified epilithic Lithocodium crusts envelop completely the shells (Fig. 5g, h). Other skeletal cavities with a round cross-section show a partial lining of the walls with Lithocodium. The transition from better to less calcified algal tissue marks hereby the assumed growth direction (Fig. 5a). However, given that it is rather unlikely that Lithocodium was able to grow into a basal part of a cavity filled by geopetal sediment, this concrete observation in Fig. 5a can be interpreted as an indication of overturning. In cases, the geopetal filling postdated the formation of the cryptic Lithocodium stage (Fig. 8c).

\section{Boreholes}

Lithophagid bivalves bored the substrates either before or after they became encrusted by Lithocodium. In the latter case, the borings affected the already lithified Lithocodium crusts down into the encrusted substrates (Fig. 5b). In the first case, the elongated empty borings (ichnogenus Gastrochaenolites) may have been completely filled by the poorly calcified cryptic growth stage of Lithocodium, which at the entrance of the boring became overgrown by the typical thicker and well-calcified Lithocodium-crusts (Fig. 5c). Borings that penetrated already lithified crusts were occupied by the cryptic Lithocodium stage, which were attached to the inner side walls, but without completely lining it (Fig. 5b). This pattern is also observable in borings penetrating the coral substrate (Fig. 6c). The partial encrustation within the crypt presumably refers to its base. When borings became rapidly filled with internal 

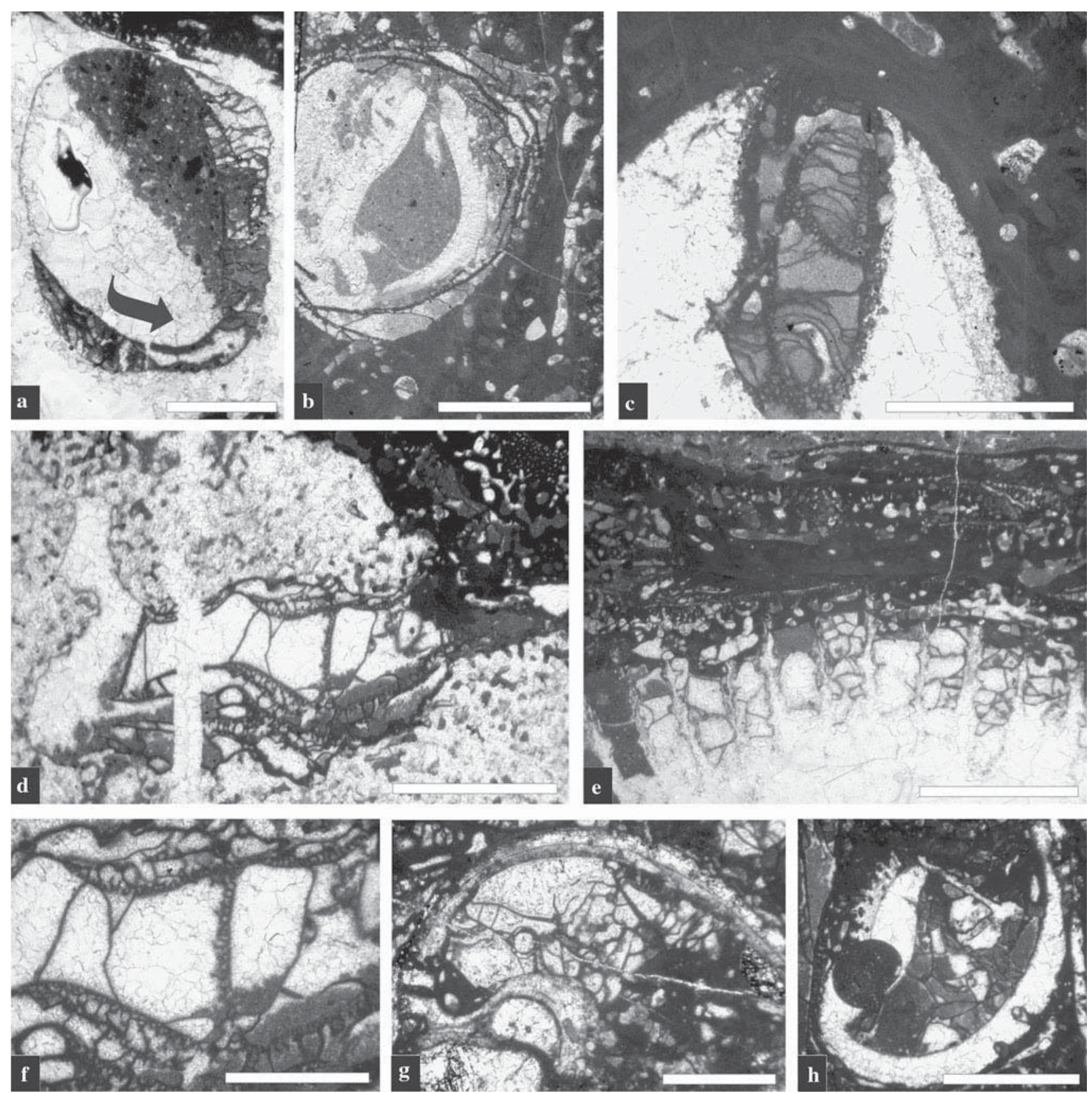

Fig. 5 Existing cryptic habitats $(\mathbf{a}, \mathbf{c}-\mathbf{h})$ and synsedimentary created crypts (b), Lower Aptian of the western Maestrat Basin, Spain. a Cavity within a bioclast showing partial geopetal filling; and its walls partly encrusted by Lithocodium aggregatum Elliott. The transition from better to less-calcified tissue marks the assumed direction of growth (arrow). The geopetal fabric obviously resulted from later overturning. b Empty boring of lithophagid bivalve (ichnogenus Gastrochaenolites) excavated in already lithified crusts of Lithocodium aggregatum Elliott. Note the single- (below) to multilayered cryptoendolithic crusts of Lithocodium aggregatum Elliott attaching to the boring side wall. c Macroboring within coral completely filled by poorly calcified crusts of Lithocodium aggregatum Elliott that exhibit full dark microcrystalline massive calcification when reaching the transition from the crypt to the substrate surface on the right. d Sculptured coral surface with poorly calcified laminae of Lithocodium aggregatum Elliott grading into substrateparallel well-calcified juxtaposed crusts. e Sculptured coral surface with rather broad ridges occupied by cellular cryptic stage of Lithocodium; at the substrate surface grading into the epilithic growth stage. f Detail from d showing the poorly calcified crusts of Lithocodium aggregatum attaching to the opponent sides of the crypt; the remaining space is filled by vertical laminae, partly with denticulated edge (=distal calcified part of the final erect filaments). $\mathbf{g}$, h Pelecypod shells that provided a sheltered void that became filled with the cryptic Lithocodium tissue. The shells themselves are totally enveloped by well-calcified Lithocodium crusts. Scale bars $1 \mathrm{~mm}$, except $\mathbf{c}-\mathbf{e}, \mathbf{h}=2 \mathrm{~mm}$. Thin-sections: a CA $2 \mathrm{H}, \mathbf{b}, \mathbf{c}, \mathbf{e} \mathrm{HO} 11 \mathrm{~V}$, d, f DE $4 \mathrm{H}, \mathbf{g}$ SE $2 \mathrm{H}, \mathbf{h}$ CUB 41 

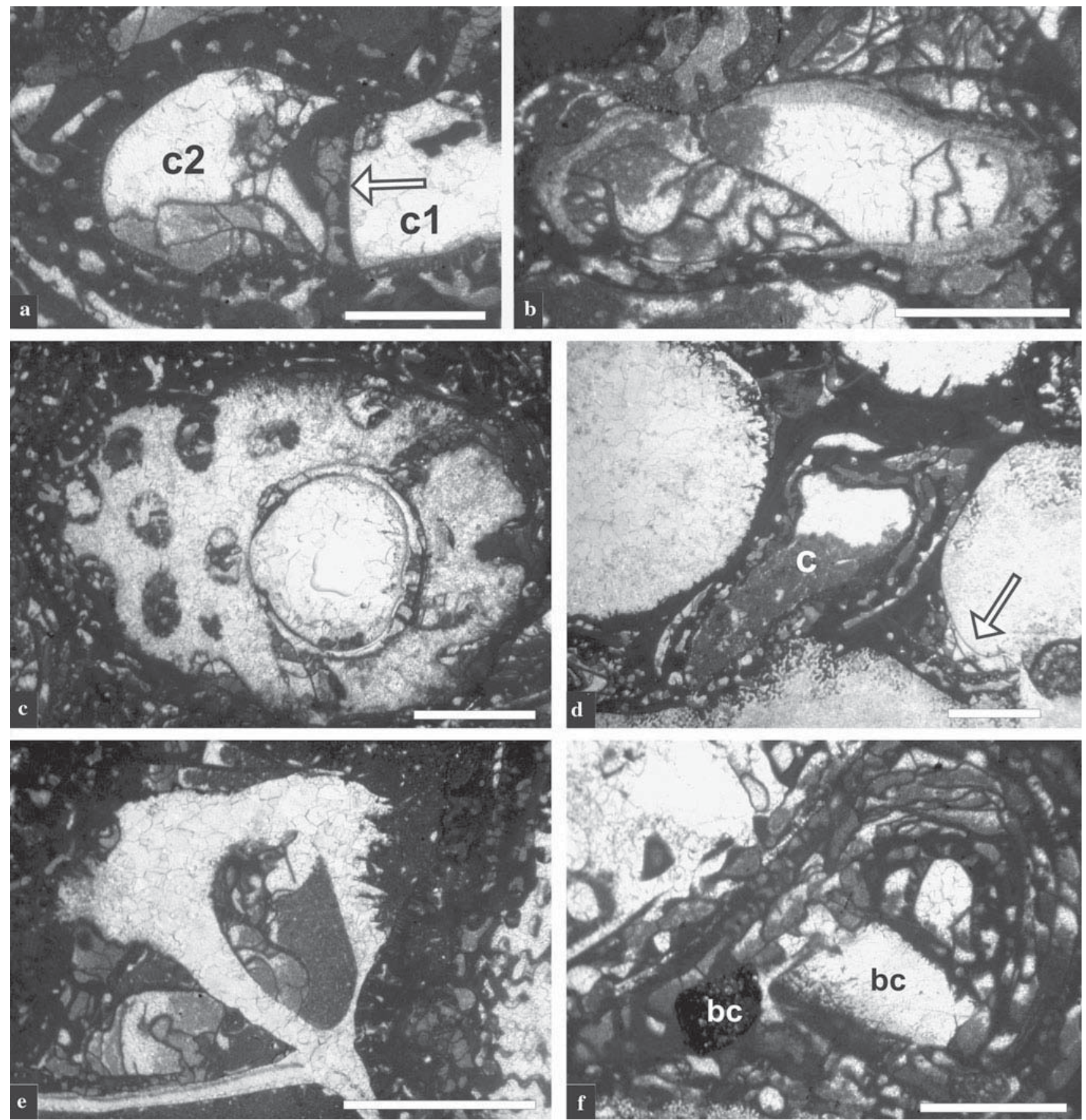

Fig. 6 Existing crypts (b, e), synsedimentary created crypts (c) and crypts produced by Lithocodium aggregatum Elliott itself (a, d, f), Lower Aptian of the western Maestrat Basin, Spain. a Crypt produced by the growth of Lithocodium itself $(c 1)$. With a bridging crust (arrow) between the opposite sides of the crypt it became closed and a secondary crypt $(c 2)$ was created that partly became filled with the cryptic growth stage. b Bioclast (tube or shell) encrusted by Lithocodium agregatum. The interior is partly filled with the cryptic growth stage. c Coral colony massively encrusted by Lithocodium aggregatum. The cryptic growth stage is partly lining the inner side walls of a bivalve boring. d Corals encrusted by Lithocodium aggregatum. Observe the successive crust formation, and how a crypt

was formed $(c)$ whose side walls were partly filled with the cryptic growth stage. Afterwards, the resulting voids were geopetally filled with sediment. Note the cryptic growth stage also at the place where two corals are closely attaching with a sheltered space between (arrow). e Cryptic growth stage of Lithocodium aggregatum within a completely recrystallized bioclast, presumably a pelecypod shell. f Crypt created by the all-side enveloping of Lithocodium crusts, almost completely filled (closed) by the cryptic growth stage. Note the enveloping of bioclasts $(b c)$ that were entering the void during its filling. Scale bars $1 \mathrm{~mm}$, except $\mathbf{c}-\mathbf{e}=2 \mathrm{~mm}$. Thin-sections: a CUB 4, b, e, f HO $116 \mathrm{~V}, \mathbf{c}$ CUB 41, d, HO 3VB 
geopetal sediment, the cryptic Lithocodium stage may occur attached to the roof (=hard substrate) of the remaining free space, and not at the surface of the finegrained filling sediment (=soft bottom) (Fig. 8f). This fact documents the occurrence of hard substrates as a prerequisite for the settlement of Lithocodium.

\section{Crypts created by Lithocodium itself}

With the bridging between adjacent bioclasts, the crusts often formed small cavities that were surrounded in all directions by Lithocodium (e.g., Figs. 3, 4, 6a, d, f, 7, 8a, c-e). Therefore, these can be termed as self-made or secondary crypts. Depending on the crypt dimensions and obviously also on the presence/absence and size of connections to the surroundings, these can be partly (e.g., Fig. 7c, j, k) or completely occupied with the cellular cryptic Lithocodium stage (Figs. 7h, 8e), or partly (Fig. 7d, e) or totally filled with sediment (Fig. 7c, f). A complete filling of the void with Lithocodium tissue was only observed in very small crypts. It is supposed that the algal tissue inside the crypt occurs at its base, with a roof often without encrustations (Fig. 7). Besides fine-grained matrix, only bioclasts (e.g., orbitolinid tests), from the surroundings rarely entered the crypts. This fact indicates that in such cases they were open to the exterior (Fig. 71). In smaller crypts this debris may totally become overcrusted by the algal tissue (Fig. 6f). The crypt walls are in almost all cases occupied only by the cryptic growth stage of Lithocodium. Extremely rare, small serpulid tubes or encrusting foraminifera occur attached to the crypt walls composed of Lithocodium aggregatum, then becoming overgrown by its cryptic stage (Fig. 9b). In some cases, a crypt was separated by a Lithocodium crust bridging between the opposite side walls, thus separating a further, secondary crypt that again may became filled with the cryptic growth stage (Fig. 6a).

Microstructure of the cryptic growth stage of Lithocodium aggregatum

The irregular vesicular cryptic growth stage may be present either in fractures and cavities of the bioclastic substrates before becoming encrusted or may represent the final stage occurring in voids/crypts that came into existence by borings or by the special growth of Lithocodium leaving free spaces (Fig. 9). Depending on the width of the voids in the basal substrate, bended microcrystalline laminae are spanning just from one side to the other (Fig. 9i) or in wider crypts, a card-house like structure of supporting microcrystalline laminae was formed (e.g., Figs. 5e, 9h). Besides thin structureless laminae, there are also thicker ones showing a denticulated side. This growth stage develops continuously from the flat epilithic crusts in a way that the calcification becomes reduced successively and the prostrate change into a thicker and more irregular shape (Fig. 9j, k, Schlagintweit et al. 2010 for further details). In a medium stage, the erect system is only recognizable by the terminal parts of the last order filaments giving rise to denticulated laminae (e.g., Fig. 9e). Being substrate-parallel the denticulated laminae occur on the roof of the cells. When the laminae bend, the growth direction is indicated by the smooth side with the denticulated side pointing into the cellular algal tissue (e.g., Fig. 9e). In a final stage, the epilithic stage is no more recognizable and there are only giant cells with a thin microcrystalline sheet (e.g., Fig. 9d, e, pars).

\section{Discussion}

Substrate availability is often the limiting factor for epilithic benthic organisms. Thus, mechanisms and strategies for acquiring areas to attach themselves are fundamental for these groups. Given that other microencrusters (serpulids, bryozoans, foraminifera, red algae, e.g., Polystrata alba) are of subordinate importance in the material studied, interspecific substrate competition dominates. From the later mentioned microencrusters, only the foraminifera Bdelloidina urgonensis is common and, often alternates with Lithocodium aggregatum crusts (see Schlagintweit et al. 2010, Table 1). Given that Lithocodium was the first colonizer of the rubble substrates, it can be regarded as a monotypic pioneer community. For this reason, a rather rapid growth and thus occupation of available substrates can be assumed. With this assumption and a supposedly high productive output, Lithocodium aggregatum fulfils main important criteria for a so-called opportunistic taxon, capable of thriving in stressed environments (Littler and Littler 1980).

It is generally assumed that the prostrate filaments of Lithocodium were attaching and creeping over the substrate showing successive branching and thus radiating in all directions in order to achieve a complete enveloping of the bioclastic debris. For this purpose, Lithocodium developed differentiated structural adaptations and special growth strategies in direct dependence on the substrate surface morphology. With the aim to closely attach to the substrate the basal part of Lithocodium was forced to adapt to various types of surface structures. With this respect, no substrate preference is known from Lithocodium. The different adaptions allowed Lithocodium to attach and eventually encrust all types of ornamented and sculptured surfaces. In that manner, also highly sculptured surfaces could have been successfully occupied by spanning bridges between spines of the irregular surfaces. With the availability to 

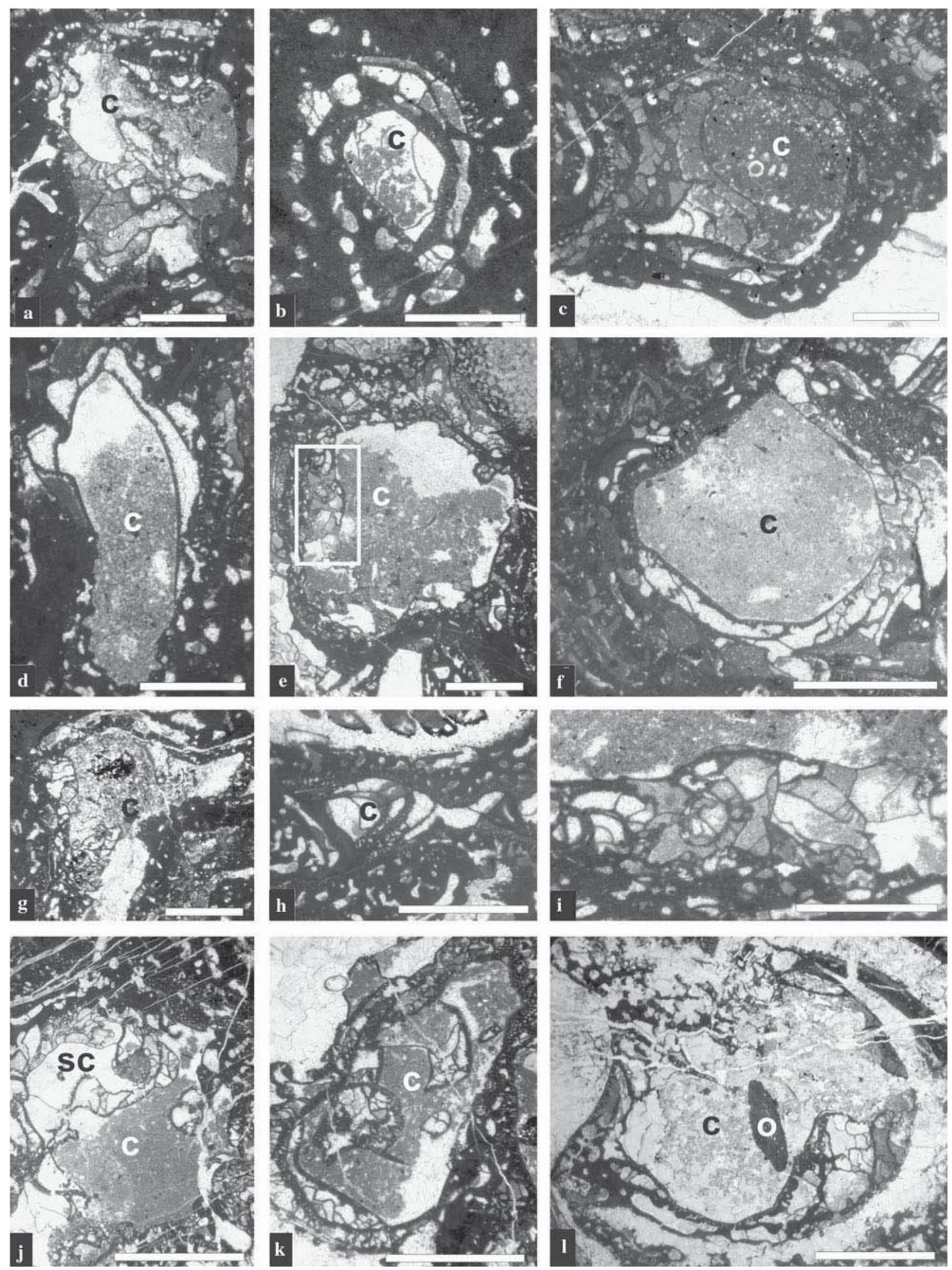
Fig. 7 Crypts produced by Lithocodium aggregatum Elliott itself $(\mathbf{a}-\mathbf{j})$ and existing crypts $(\mathbf{k}, \mathbf{l})$ exhibiting the development of the poorly calcified aberrant cryptic Lithocodium growth stage, Lower Aptian of the western Maestrat Basin, Spain. a Crypt (c) filled by the cryptic Lithocodium stage and sediment. Note that the cryptic growth stage is much better developed on one side of the crypt indicating some kind of triggering mechanism such as, for example, photo- or geotaxis. b Small crypt $(c)$, more or less completely filled with the cryptic growth stage exhibiting internal sediment. Note the well visible all-side enveloping of Lithocodium crusts around the crypt. c Comparable large, sediment-filled crypt (c) exhibiting growth polarity of the cryptic Lithocodium growth stage (see also a). d Elongated crypt $(c)$ with geopetal internal sediment and the cryptic Lithocodium growth stage developed on the upper side (?downward growth). e Large crypt (c) with geopetal internal sediment. In contrast to d, the cryptic Lithocodium growth stage is not developed on the supposed upper side of the crypt. The white rectangle marks the detail shown in i. f Large, sediment-filled crypt (c) with cryptic Lithocodium stage displaying growth polarity. g, h Small crypts (c), partly (g) or completely filled with cryptic Lithocodium growth stage (h). i Detail of the aberrant cryptic Lithocodium growth stage. $\mathbf{j}-\mathbf{l}$ Comparable large crypts $(c)$ showing growth polarity of the cryptic Lithocodium growth stage. The sparite-filled void surrounded by the cryptic Lithocodium stage is supposed to represent a secondary crypt (sc), not part of the alga. The orbitolinid test $(o)$ in the centre of $\mathbf{l}$ documents that the void was not completely sheltered from all sides but was connected to the exterior. Scale bars $1 \mathrm{~mm}$ except $\mathbf{e}, \mathbf{f}, \mathbf{h}, \mathbf{j}-\mathbf{l}$. Thinsections: a CA $2 \mathrm{H}$, b CAL $2 \mathrm{~V}$, c CUB 4, d DE $3 \mathrm{H}$, e, i HO $4 \mathrm{HB}$, f HO $6 \mathrm{~V}, \mathbf{g}$ HO $17 \mathrm{~V}, \mathbf{h}$ DE $4 \mathrm{~V}, \mathbf{j}$ CAL $5 \mathrm{~V}, \mathbf{k}$ PO $1 \mathrm{~V}, \mathbf{l}$ HO $8 \mathrm{~V}$

form interconnecting bridges between individual bioclasts, the unstable bioclastic deposit/substrate became successively stabilized, forming a massive rigid structure. With this respect, the massive Lithocodium-coral constructions can be compared to a certain extent with modern coral reef rubble deposits (Bover-Arnal 2010; Bover-Arnal et al. 2011). By this analogy, Lithocodium prerecorded the role of what red algae and diagenetic cementation do in modern reefal environments being highest in fore-reefal settings (e.g., Rasser and Riegl 2002).

In larger voids still open to the exterior, millimeter-sized bioclasts such as orbitolinid tests could enter and often became totally encrusted by the cryptic Lithocodium tissue. It is important to emphasize that the bioclasts were not agglutinated (=incorporated in the micritic algal tissue), but simply became overgrown by Lithocodium. This becomes especially evident when larger individual bioclasts (corals) became totally encrusted. The differentiation between agglutination/trapping and simple overgrowth or growing around and thus assimilate skeletal structures makes an important difference with respect to the biologic interpretation of Lithocodium (Schlagintweit et al. 2010 for details). Let us remember, that trapping is the retention of tiny sedimentary particles on a surface, e.g., of a microbial mat, from where microbes bind these particles over time during mat fabric formation (e.g., Black 1933; Riding 1991; Noffke 2008).

About $80-90 \%$ of our material shows the development of Lithocodium aggregatum just as superimposed flat crusts of variable thickness with well-differentiated prostrate basal and erect filaments. From the overall abundances this type can be attributed as the dominating growth type. The vesicular growth type is more seldom; if not abnormal it can at least be approached as irregular. Its appearance is so dissimilar in appearance compared to the flat epilithic crusts, that one could classify it as a separate taxon when sections not showing the continuous development from one stage to the other are not available. But what were the reasons for Lithocodium to develop this anomalous growth fabric of obvious reduced capability to calcify? For modern marine benthic macroalgae, the adaptive significance of the thallus morphology in relationship to ecological interactions and physiological functions was used for a functional-form grouping (Littler and Littler 1980). This functional-form hypothesis or concept, implying the intimate relationship of morphology and physiological function, has been successfully tested in predicting and explaining morphological adaptations in various taxa of marine macroalgae (e.g., Littler 1980; Littler and Arnold 1982; Littler et al. 1983; Littler and Littler 1983; Hay 1986; Kilar 1989; Hanisak et al. 1988, 1990; Steneck and Dethier 1994; Gacia et al. 1996). But there are exceptions to this model revealing more complex explanations (Padilla and Allen 2000). As previously assumed, the availability of space in the voids as a limiting factor can be excluded since this Lithocodium growth stage occurs in both close (e.g., furrows in the encrusted skeletal substrate) and wide spaces (e.g., the interior of Gastrochaenolites borings). Because of the reduced sizes of cryptic microhabitats, also other factors as reaction to predation, hydrodynamic stress or competition seems to be negligible. The extreme rarity of other attaching microorganisms in the voids, e.g., serpulids or encrusting foraminifera, however, results in a low cryptobiontic diversity. It is evident that environmental parameters affecting growth/calcification were not always constant during part of the crusts formation and obviously accounted for these differences. As a common factor of these protected microhabitats, a reduced light availability, as typical for cryptic habitats, is evident and is considered the key factor for the aberrant morphological structure of Lithocodium. In the case of structural cavities inside the substrate, this growth stage can be termed initial or basal cryptic growth stage (=chasmoendolithic basal stage sensu Schlagintweit et al. 2010), and the latter as final cryptic growth stage (=vesicular terminal stage sensu Schlagintweit et al. 2010), as both are almost identical in its microstructure. For the basal cryptic stage there are two principal possibilities: (1) colonization started within the crypt/fissure growing upward, then grading into the epilithic growth stage when the substrate surface was reached (2) filling downward from a creeping crust arriving at the crypt and overgrowing it (Figs. 5c, e, 8f, i). A convincing 

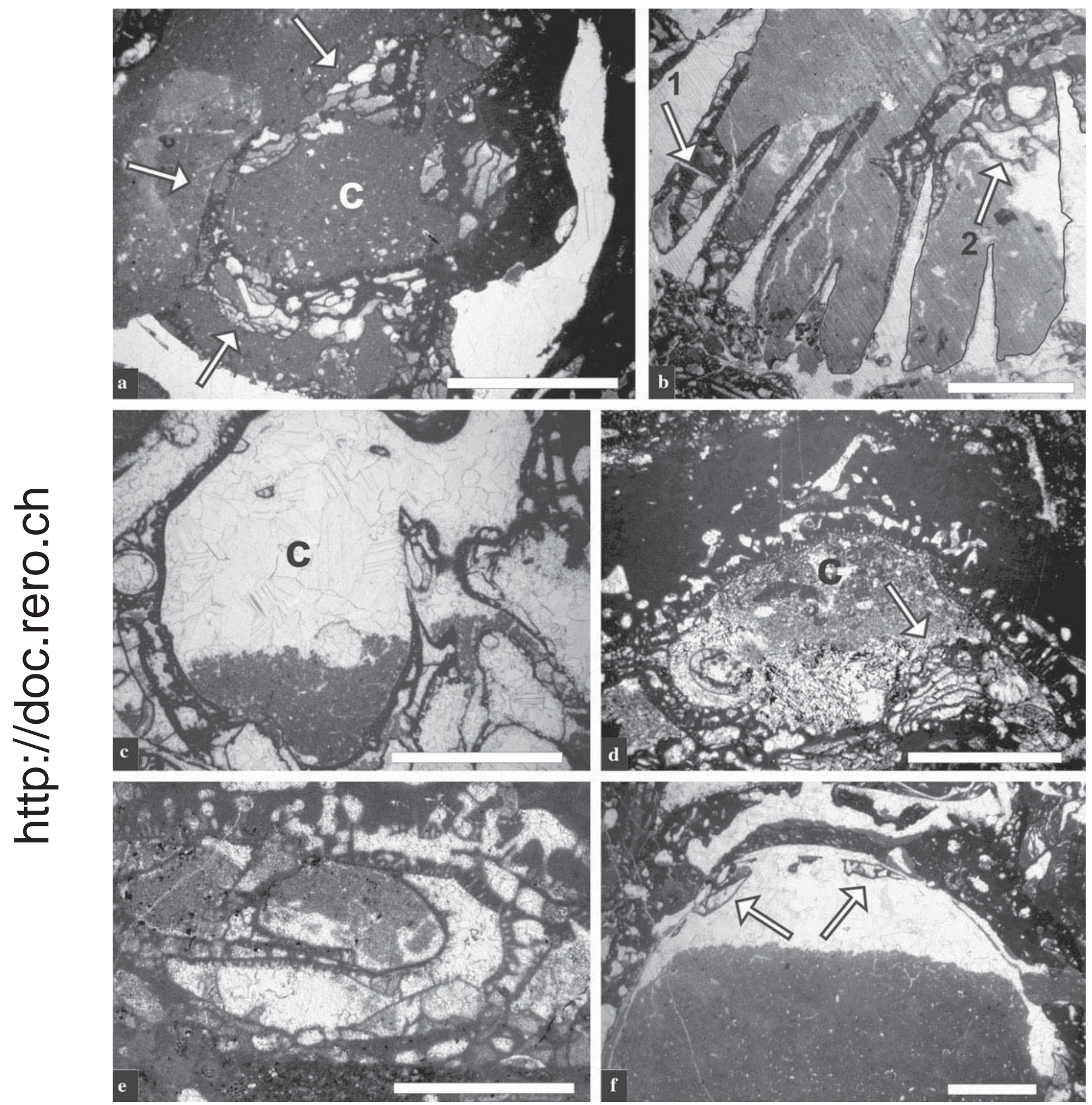

documentation of either one of the two possibilities cannot be presented at the moment. In any case, the downward growth of prostrate filaments, the sharp bending at the bottom in the opposite direction, followed by upward growth was obviously impossible in furrows or fractures of reduced width. Besides the shading effect within the crypts, also the successive overgrowth of Lithocodium-crusts by the next layer must have had a comparable effect. In this case, however, the lower crusts could not react in the same way. Perhaps this also caused the death of the deeper crusts when they became thickly encrusted. The often observed micritization of the filamentous system of inner crusts can be an indication for such an assumption. Otherwise, the thin poorly calcified crusts with reduced erect system 
4 Fig. 8 Existing crypts $(\mathbf{a}-\mathbf{c}, \mathbf{f})$ and crypts produced by Lithocodium aggregatum Elliott itself (d, e) exhibiting the development of the poorly calcified aberrant cryptic Lithocodium growth stage, Lower Aptian of the western Maestrat Basin, Spain. a Small sediment-filled cavity $(c)$ surrounded by cryptic Lithocodium growth stage. At the lower side, the crustose fabric became detached from the substrate (arrow); the same can be observed on the left side where the substrate has been moved away (arrows). b Single-layered crusts of Lithocodium aggregatum upon a spinose (or ridged) substrate surface. Within the two furrows on between the spines (or ridges) on the left, the bottom is filled with the vesicular cryptic growth stage (arrow 1). On the right side, Lithocodium bridges two spines. The resulting basal void is not occupied by Lithocodium; note the evolution of vesicular cryptic stage at the base of the bridge (arrow 2). c Crypt exhibiting geopetal filling, surrounded from all sides by the cryptic Lithocodium growth stage. d Crypt $(c)$ surrounded by thick massive crusts of Lithocodium. At the lower side (? former crypt bottom), the cryptic growth stage can be noticed (arrow). e Small crypt produced by Lithocodium aggregatum Elliott. f Pelecypod shell encrusted by Lithocodium aggregatum at the exterior surface; the inner hollow is almost completely filled with geopetal sediment. In the remaining free space, the cryptic Lithocodium stage was attaching to its roof. Scale bars $2 \mathrm{~mm}$, except $\mathbf{e}=1 \mathrm{~mm}$. Thin-sections: a DE $3 \mathrm{~V}$, b DE $5 \mathrm{H}$, c PO1 V, d HO $17 \mathrm{~V}$, e CUB 4, f HO $6 \mathrm{~V}$

occurring in thick crustose masses (e.g., Fig. 2b), but never observed as pioneer crust upon the substrate, could be a time-equivalent reaction to ongoing encrustation by younger crusts and thus a distinct reduction in light availability. Generally overgrowth is assumed to be a disadvantage for the underlying organism with negative effects including for example reduced growth (e.g., Airoldi 2000). From some modern encrusting red algae, for example, it is well known that they can withstand shading and overgrowth for long periods thanks to connections to unshaded parts of the thallus (e.g., Bulleri 2006; Underwood 2006). In this respect, translocation of nutrients across their thalli was possible to some degree, thus enabling the alga to survive being overgrown a certain period. In the same manner, some peysonneliacean algae display decreasing crust thicknesses with increasing water depth as the lower tissue of thicker crusts only receives little light (Dethier et al. 1991). The thin and poorly calcified Lithocodiumcrusts were obviously misinterpreted by Embry et al. (2010, Fig. 6b) as belonging to the alga Thaumatoporella but in fact represent thin crusts of Lithocodium with reduction of the erect system. Noteworthy that thaumatoporellaceans might in fact be present within bacinellid fabrics (e.g., Schäfer and Senowbari-Daryan 1983) but were not observed in any of the thin-sections studied. It is worth to mention that examples of varying calcification reported from modern marine algae are related to different water depths as controlling factor for light intensity. In our case, the light reduction was not attended with a deepening but with sheltering effects. Among modern calcareous algae, the relationship between light (or depth) and degree of calcification is not directly correlative within and also between different groups (red algae, green algae). For example, most calcareous green algae (e.g., Penicillus, Udotea, Rhipocephalus) are invariably more calcified in shallow water, it is the opposite in Halimeda that tends to be more heavily calcified in deeper than in shallow water (Goreau 1963; Borowitzka and Larkum 1976). With this respect, Lithocodium obviously can be placed in the group exhibiting light-enhanced calcification. One fossil example for a facultative cryptic calcareous green algae showing morphological adaptation is represented by Mesozoic thaumatoporellacean algae. They generally show a wide morphological range within Mesozoic shallow-water platform carbonates (De Castro 1990, for details). De Castro (1990, p. 198) described and figured Liassic thaumatoporellaceans inside gastropod shells, noting their very thin walls and speculated that this character could be related to insufficient light availability. Cryptobiotic thaumatoporellaceans were recently also detected in the tests of larger benthic foraminifera and inside the thalli of dasycladalean algae (Schlagintweit and Velić 2011). When possessing the possibility, it seems obvious that the aim of the morphological reaction of light-dependent calcareous algae to shaded habitats is to maximize light capture for photosynthesis. In modern green algae, for example, short-term photoadaptation can be measured by changes in the photochemical activity (e.g., Koblížek et al. 1999). According to the Littler-model, the individual thallus gross morphology that directly accounts for its surface-area: volume (SA: V) ratio, relates to the effectivity of nutrient uptake and photosynthesis. Thus, a large surface-to-volume ratio, for instance, improves light and nutritional fluxes across the algal surface. It seems likely that with the development of large cellular structures, the cryptic Lithocodium growth stage increased the surface area to capture most of the incident light. As a general rule, however, the surface area decreases proportionally as mass increases with shape held constant. Therefore, a multitude of bended cells lacking a common smooth surface were created in the cryptic Lithocodium stage in order to increase the surface area. Furthermore, the thin walls facilitated light penetration inside the algal tissue by minimizing the so-called selfshading by non-photosynthetic wall components (Littler and Littler 1980, for details). In modern algal communities, e.g., seaweeds, competition is one of the major selective factors and that success in the competition for light is considered the basis for wins in space (e.g., Nabivailo and Titlyanov 2006). Summarizing, the morphological heteromorphism of Lithocodium aggregatum Elliott explained as a high plasticity in photosynthetic adaptation can be considered a fossil example that fits the functional-form model.

Although showing light-dependent growth, the occurrence in cryptic habitats clearly demonstrates that one must act with caution when using the occurrence of Lithocodium 

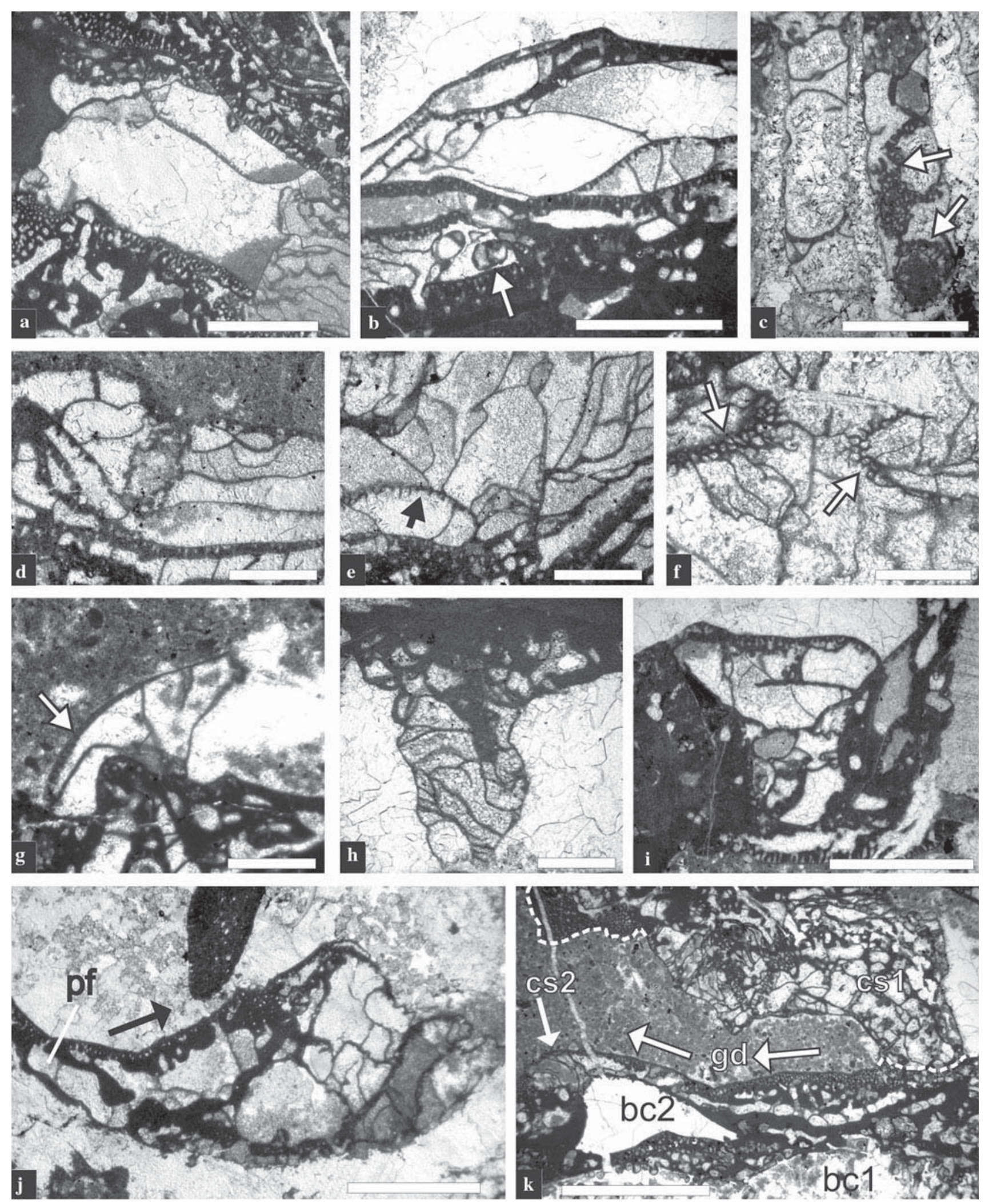

aggregatum as a depth indicator, respectively, as an indicator for shallow-water settings. For Upper Jurassic material for example, Schmid and Leinfelder (1996) concluded that Lithocodium aggregatum represents a "valuable palaeoecological indicator" with dependence "on shallow, hence illuminated, water". Taken the supposed restriction 
Fig. 9 Microstructure of the basal $(\mathbf{c}, \mathbf{h})$ and final $(\mathbf{a}-\mathbf{b}, \mathbf{d}-\mathbf{g}, \mathbf{i}-$ k) cryptic growth stage of Lithocodium aggregatum Elliott from the Lower Aptian of the western Maestrat Basin, Spain. a-d Thin-walled and poorly calcified cellular tissue representing the homeomorphic equivalent to the prostrate and erect system of Lithocodium aggregatum. The terminal upper part of each crust is represented by a comparably thicker micritic layer showing the short preserved terminations of the last order of the erect filaments (arrows in b-d). e, i Basal cryptic stage within coral skeletal structures. In i, the terminal sheath layer (compare a-d) is visible (arrows). f Bridgeforming cryptic stage. g Cryptic stage within a void completely enclosed by Lithocodium crusts. h Cryptic final stage within a cavity. The epilithic stage of Lithocodium is encrusted by a serpulid (arrow) that subsequently became overgrown by the cryptic stage. j Lithocodium aggregatum crust upon a skeletal substrate; in the growth direction (black arrow), the terminal cryptic stage evolves directly from the prostrate filaments $(p f)$. k Cavity between encrusted bioclasts (bc 1) with the cryptic final stage (cs 1) bridging between the two opposite side walls. At the lower side, the irregular poorly calcified cryptic stage ( $c s$ 2) evolves in the growth direction $(g d)$ from the prostrate system upon an overgrown supposed bioclast (bc 2). Scale bars $0.5 \mathrm{~mm}$ for $\mathbf{a}-\mathbf{e}, 1 \mathrm{~mm}$ for $\mathbf{f}-\mathbf{j}, 2 \mathrm{~mm}$ for $\mathbf{k}$. Thin-sections: $\mathbf{a}$, b CAL $5 \mathrm{~V}$, c HO $3 \mathrm{VB}, \mathbf{d} H O 6 \mathrm{~V}$, e, f, h PO $1 \mathrm{~V}, \mathbf{g}$ HO $11 \mathrm{~V}$, i SE $2 \mathrm{H}, \mathbf{j}$ HO $8 \mathrm{~V}, \mathbf{k}$ CAL $6 \mathrm{~V}$

of Lithocodium to internal settings above the fair-weather wave base (Leinfelder et al. 1993; Leinfelder 2001), it should therefore be indicative for depths of approximately 10-20 m (e.g., Tucker and Wright 1990). However, the data obtained from the Late Jurassic material are not directly consistent with that from the Lower Cretaceous. For Lithocodium-rich facies from the Hauterivian and Lower Aptian of the Middle East, water depths from ca. 15 to ca. $60 \mathrm{~m}$ (Banner et al. 1990) or 30-60 m (Hughes 2000, p. 563) are assumed, for instance by the associated microfauna (Neotrocholina, small planktic foraminifera) and by its relative position within shallowing-upwards succession from basinal to inner platform depositional environments. Bover-Arnal (2010) and Bover-Arnal et al. (2011) state that the Lithocodium-bearing coral rubble horizon exposed in the western Maestrat Basin (Spain), was developed in basinal settings, sheltered from continuous water motion, on account of the large amount of micrite matrix exhibited by the lithofacies, the absence of early diagenetic cements, the rarity of Lithocodium oncoidal forms, and the accompanying biota, such as solitary corals, brachiopods and large-sized discoidal Palorbitolina lenticularis. For the same deposits, Embry et al. (2010, Fig. 6) attributed the Lithocodium-rich facies to a depositional setting reaching from the lower "shoreface" down to the distal "upper offshore", below the fair weather wave base. Also from the Maestrat Basin, but from the Upper Aptian, Tomás et al. (2008, Fig. 3) described "coral-algalsheetstones" with Lithocodium-Bacinella, that, due to the "low-light and nutrient-rich" coral assemblage, were attributed to the proximal outer ramp below storm-wave base, deeper than the fair weather-wave base. The same conclusion was reached by Götz et al. (2005) for Lithocodium-rich facies of the Late Hauterivian of the Maestrat Basin.

Summarizing, from the literature data, there seems to be a discrepancy for the assumed palaeowater depths of Upper Jurassic and Lower Cretaceous Lithocodium-rich carbonates. The main reason for this discrepancy obviously resulted from the circumstance that "Lithocodium aggregatum Elliott" sensu Schmid and Leinfelder 1996 is taxonomically different. As recently interpreted by Schlagintweit (2010), these Late Jurassic forms represent the traces of boring sponges (ichnogenus Entobia) within calcimicrobial crusts (oncoids) of shallow-water habitats (Fig. 10a-d). In Upper Jurassic reefal carbonates (see Kolodziej 1997) and the studied Early Aptian samples, entobians were also observed boring into crusts of Lithocodium aggregatum Elliott (Fig. 10e, f). Besides such a two-taxa explanation, another reason could be, that the adaptation of Lithocodium aggregatum to "moderately deep marine, low energy conditions" (Hughes 2000, p. 138) was an evolutionary process not developing prior to the lowermost Cretaceous. An up-to-date inventory of the occurrences of "Lithocodium aggregatum" in the literature along with taxonomic considerations, evaluation of the accompanying biota and inferred water depth interpretations seems to be a prerequisite to render more precisely such a hypothesis.

\section{Conclusions}

From the investigations carried out in Lower Cretaceous material from the Maestrat Basin containing Lithocodium aggregatum Elliott, and based on its interpretation as a calcareous green alga by Schlagintweit et al. (2010), the following conclusions can be drawn:

1. In order to achieve a rapid and complete encrustation of biogenic deposits, the epilithic Lithocodium aggregatum was growing by means of its prostrate creeping filament system that branches and radiates over the substrate surfaces. As an opportunistic taxon, Lithocodium did not exhibit any substrate-specificity and was able to colonize effectively both smooth and variously sculptured surfaces. It was also able to form projections away from the substrate, thus building interconnections to adjacent bioclasts, here referred to as "Lithocodium bridges". With its special growth strategies, Lithocodium thus stabilized the loose bioclastic deposit/substrate by forming a rigid structure. The resulting massive Lithocodium-coral constructions can be compared with modern coral reef rubble deposit 

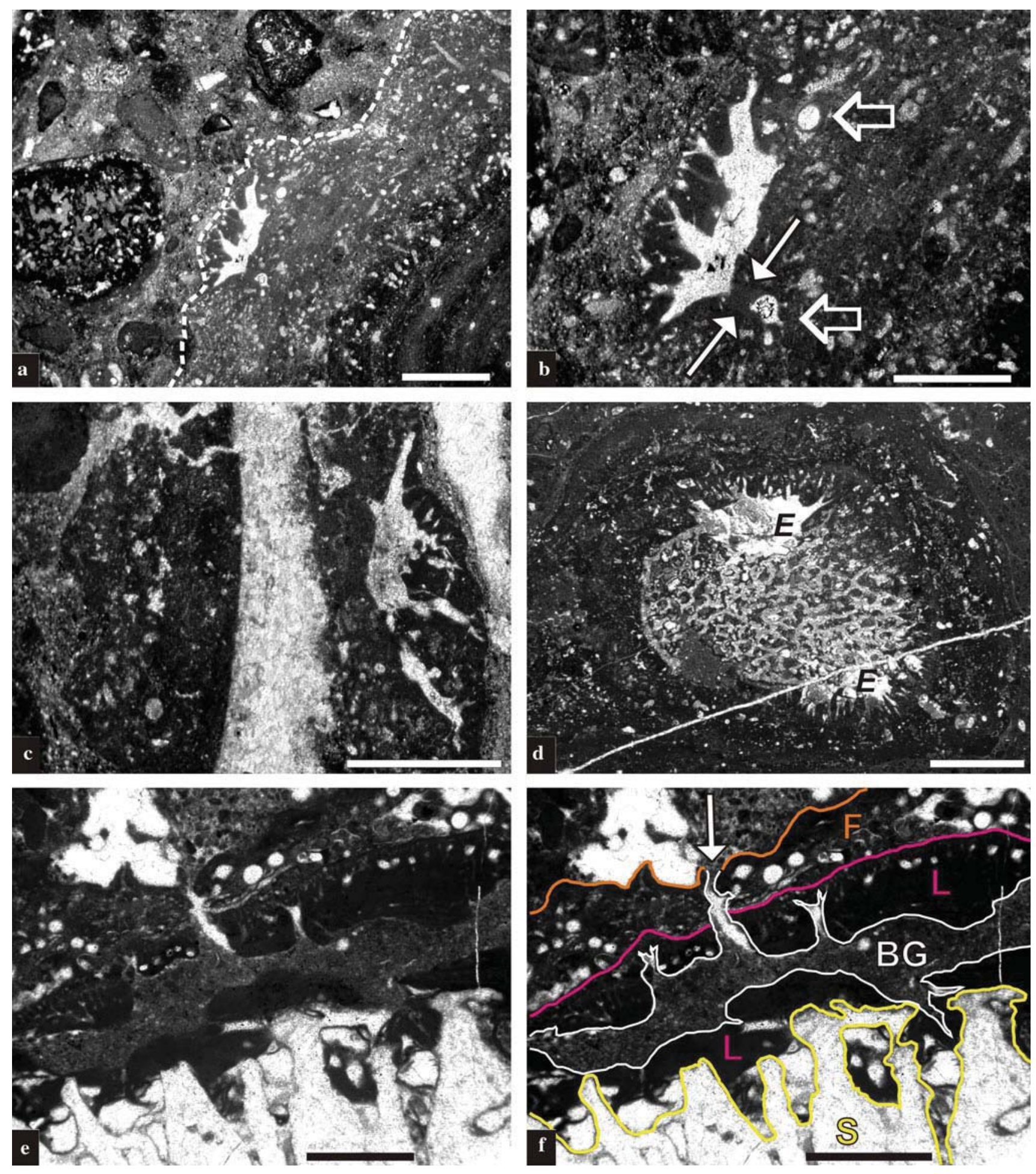

stabilization where Lithocodium prerecorded the role what red algae and diagenetic cementation do in these environments.

2. Between the bioclast-crust-masses, free spaces (cavities or crypts) surrounded from all sides by Lithocodium crusts were created. Besides these, two other

types of crypts have been recognized: already existing in the bioclasts before becoming encrusted and boreholes cutting into both the already lithified crusts of Lithocodium and the encrusted bioclasts. Within the crypts, Lithocodium developed an irregular growth fabric attended by a reduction of both the erect 
4 Fig. 10 a Oncoid floatstone exhibiting macroborings of excavating sponges. The white dashed line marks the boundary of the large oncoid shown in b. b Empty chamber of a boring sponge (Entobia isp. $1=$ "Lithocodium aggregatum Elliott" sensu Schmid and Leinfelder 1996); further details in Schlagintweit (2010). c Entobia exhibiting one chamber and radiating canals within calcimicrobial crust enveloping a pelecypod shell. Late Tithonian or Early Berriasian of the Northern Calcareous Alps, Austria. d Two specimens of Entobia boring into a stromatoporoid skeleton and canals radiating into oncoidal crusts. Late Tithonian-Early Berriasian of Crimea Mountains, Ukraine (detail from Krajewski 2010, fig. 4.61.A). e, f Sediment-filled boring gallery $(B G$, white line) produced by a excavating sponge within Lithocodium-crusts ( $L$, red line) overlain by arenaceous foraminifera ( $F$, orange line) and resting upon a coral skeleton as substrate ( $s$, yellow line). The opening (white arrow) transecting the foraminiferan-Lithocodium-crusts is interpreted as an osculum. Note the large upright diverging canals/boring filaments cutting through the fine-branching erect filament system of Lithocodium. Late TithonianEarly Berriasian Stramberk Limestone of the Polish Carpathians (see Kolodziej 1997). Scale bars $1.0 \mathrm{~mm}$ for a, c-d, $0.5 \mathrm{~mm}$ for $\mathbf{b}$

filament system and the degree of thallus calcification as well as increasing cell size. In both modern and fossil taxa, such extreme morphological variability is often suggested as representing different species but as also in the case of Lithocodium aggregatum is just a further example of cryptic heteromorphism or phenotypic plasticity. It is interpreted as the morphological reaction of a light-dependent calcareous alga to shaded habitats in order to maximize light capture for photosynthesis by increasing the thallus surface-area: volume ratio. The morphological heteromorphism of Lithocodium aggregatum Elliott can therefore be considered a fossil example, which permits, at least to some extent, the application of the functional-form concept developed for modern marine benthic macroalgae.

3. Lithocodium can on the one hand be placed in the group of calcareous algae exhibiting a light-enhanced calcification, but on the other hand possessed the ability to tolerate a certain degree of reduced illumination. Nonetheless, Lithocodium cannot be considered a cryptic microorganism. In addition, its occurrence within crypts demonstrates that Lithocodium aggregatum can also not per se be considered a meaningful indicator for shallow water conditions. Bearing in mind that cryptic microhabitats may be present also in shallow-water, each case must be carefully considered including analysis of the accompanying biota and the occurring morphotypes of Lithocodium.

Acknowledgments We are grateful to Sara Tomás (University of Potsdam, Germany) and Ramon Salas (Universitat de Barcelona, Spain) for allowing us to study their Late Hauterivian material from the central Maestrat Basin. Ramon Salas (Universitat de Barcelona, Spain) and Josep Anton Moreno-Bedmar (Universidad Nacional
Autónoma de México, Mexico) are acknowledged for their help in sampling in the western Maestrat Basin. Funding for this study came from the Swiss National Science Foundation grant no. 20-121545.08, the $\mathrm{I}+\mathrm{D}+\mathrm{I}$ research projects: CGL2005-07445-CO3-01 and CGL2008-04916, the Consolider-Ingenio 2010 programme, under CSD 2006-0004 “Topo-Iberia”, and the Grup Consolidat de Recerca "Geologia Sedimentària" (2005SGR-00890 and 2009SGR-1451). Boguslav Kolodziej and Marcin Krajewski (both Kraków) kindly provided two photographs for illustration. Last but not least, we thank the reviewers Matías Reolid (Granada) and Ioan Bucur (Cluj-Napoca) for valuable suggestions.

\section{References}

Airoldi L (2000) Effects of disturbance, life histories, and overgrowth on coexistence of algal crusts and turfs. Ecology 81:798-814

Allouc J, Harmelin JG (2001) Les dépôts d'enduits manganoferrifères en environnement marin littoral. L'exemple de grottes sousmarines en Méditerranée nord-occidentale. Bull Soc Géol France 172:765-778

Banner FT, Finch EM, Simmons MD (1990) On Lithocodium Elliott (Calcareous algae); its paleobiological and stratigraphical significance. J Micropaleontol 9:21-36

Bastrop R, Jürss K, Sturmbauer C (1998) Cryptic species in a marine polychaete and their independent introduction from North America to Europe. Mol Biol Evol 15:97-103

Black M (1933) The algal sediments of Andros Islands, Bahamas. R Soc Lond Philos Trans Ser B 222:165-192

Borowitzka MA, Larkum AWD (1976) Calcification in the green alga Halimeda. IV. The action of metabolic inhibitors on photosynthesis and calcification. J Exp Bot 27:894-907

Bover-Arnal T (2010) The Aptian evolution of the Galve sub-basin (Maestrat Basin; E Iberia). Unpublished PhD thesis, Universität Bayreuth, 222 pp, http://opus.ub.uni-bayreuth.de/volltexte/2010/ 671

Bover-Arnal T, Moreno-Bedmar JA, Salas R, Skelton PW, Bitzer K, Gili E (2010) Sedimentary evolution of an Aptian syn-rift carbonate system (Maestrat Basin, E Spain): effects of accommodation and environmental change. Geol Acta 8:249-280

Bover-Arnal T, Salas R, Martin-Closas M, Schlagintweit F, MorenoBedmar JA (2011) Expression of an oceanic anoxic event in a neritic setting: lower Aptian coral rubble deposits from the western Maestrat Basin (Iberian Chain, Spain). Palaios 26:18-32

Bradshaw AD (1965) Evolutionary significance of phenotypic plasticity in plants. Adv Gen 13:115-155

Bulleri F (2006) Duration of overgrowth affects survival of encrusting coralline algae. Mar Ecol Prog Ser 321:79-85

Canérot J, Crespo A, Navarro D (1979) Montalbán, hoja n ${ }^{\circ}$ 18. Mapa Geológico de España 1:50.000. $2^{\text {a }}$ Serie. $1^{\mathrm{a}}$ Edición. Servicio de Publicaciones, Ministerio de Industria y Energía, Madrid 31 pp.

Crabbe MJC, Smith DJ (2006) Brief communication: modelling variations in corallite morphology of Galaxea fascicularis coral colonies with depth and light on coastal fringing reefs in the Wakatobi Marine National Park (S.E. Sulawesi, Indonesia). Comp Biol Chem 30:155-159

De Castro P (1990) Thaumatoporelle: Conoscenze attuali e approcio all' interpretazione. Boll Soc Paleont Ital 29:179-206

Dethier MN, Paull KM, Woodbury MM (1991) Distribution and thickness patterns insubtidal encrusting algae from Washington. Bot Mar 34:201-210

Embry JC, Vennin E, Van Buchem FSP, Schroeder R, Pierre C, Aurell M (2010) Sequence stratigraphy and carbon isotope stratigraphy of an Aptian mixed carbonate-siliciclastic platform to basin transition (Galve sub-basin, NE Spain). In: Van Buchem 
FSP, Gerdes KD, Esteban M (eds) Mesozoic and Cenozoic Carbonate Systems of the Mediterranean and the Middle East: Stratigraphic and Diagenetic Reference Models. Geological Society of London Engineering Geological Special Publications, vol 329, pp 113-143

Fuller T (2003) The integrative biology of phenotypic plasticity. Biol Philos 18:381-389

Gacia E, Littler MM, Littler DS (1996) The relationships between morphology and photosynthetic parameters within the polymorphic genus Caulerpa. J Exp Mar Biol Ecol 204:209-224

Gautier F (1980) Villarluengo, hoja $\mathrm{n}^{\circ}$ 543. Mapa Geológico de España 1:50.000. $2^{\mathrm{a}}$ Serie. $1^{\mathrm{a}}$ Edición. Servicio de Publicaciones, Ministerio de Industria y Energía, Madrid 45 pp.

Golubić S, Friedmann I, Schneider J (1981) The lithobiontic ecological niche, with special reference to microorganisms. J Sed Petrol 51:475-478

Goreau TF (1963) Calcium carbonate deposition by coralline algae and corals in relation to their roles as reef-builders. Ann NY Acad Sci 109:127-167

Götz S, Löser H, Schmid DU (2005) Reef development on a deepening platform: two Early Cretaceous coralgal patch reefs (Catí, Llàcova Formation, eastern Spain) compared. Cret Res 26:864-881

Graus RR, MacIntyre IG (1982) Variation in growth forms of the reef coral Montastrea annularis (Ellis and Solander): a quantitative evaluation of growth response to light distribution using computer simulation. In: Rützler K, McIntyre IG (eds) The Atlantic barrier reef ecosystem at Carrie Bow Cay, Belize. Smithsonian Inst Press, Washington DC, pp 441-465

Guilbault JP, Krautter M, Conway KW, Vaughn Barrie J (2005) Modern foraminifera attached to hexactenillid sponge meshwork on the west Canadian shelf: comparison with Jurassic counterparts from Europe. Palaeontologia Electronica 9, http:// palaeoelectronica.org/paleo/2006_1/sponge/issue1_06.htm

Hanisak MD, Littler MM, Littler DS (1988) Significance of macroalgal polymorphism: intraspecific tests of the functionalform model. Mar Biol 99:157-165

Hanisak MD, Littler MM, Littler DS (1990) Application of the functional-form model to the culture of seaweeds. Hydrobiol 204(205):73-77

Hay ME (1986) Functional geometry of seaweeds: ecological consequences of thallus layering and shape in contrasting light environments. In: Givnish TJ (ed) On the economy of plant form and function. Cambridge University Press, Cambridge, pp 635-666

Hughes GW (2000) Bioecostratigraphy of the Shu'aiba Formation, Shaybah Field, Saudi Arabia. GeoArabia 5:545-578

Hunt G (2004) Phenotypic variation in fossil samples: modeling the consequences of time-averaging. Paleobiology 30:426-443

Jackson JBC, Goreau TF, Hartman WD (1971) Recent brachiopodcoralline sponge communities and their paleoecological significance. Science 173:623-625

Kase T, Hayami I (1992) Unique submarine mollusc fauna: composition, origin and adaptation. J Molluscan Stud 58:446-449

Kilar JA (1989) Functional-morphological relationships in Sargassum polyceratium (Phaeophyta): phenotypic and ontogenetic variability in apparent photosynthesis and dark respiration. J Phycol 25:713-720

Klaus JS, Budd AF, Heikoop JM, Fouke BW (2007) Environmental controls on corallite morphology in the reef coral Montastraea annularis. Bull Mar Sci 80:233-260

Koblížek M, Ciscato M, Komenda J, Kopencký J, Šiffel P, Masojídek J (1999) Photoadaptation in the green alga Spongiochloris sp. A three-fluorometer study. Photosynthetica 37:307-323

Kobluk DR (1988a) Cryptic faunas in reefs: ecology and geologic importance. Palaios 3:379-390

Kobluk DR (1988b) Pre-Cenozoic fossil record of cryptobionts and their presence in early reefs and mounds. Palaios 3:243-250
Kobluk DR, Lysenko MA (1987) Southern Caribbean cryptic scleractinian reef corals from Bonaire. N.A. Palaios 2:205-218

Kobluk DR, Cuffey RJ, Fonda SS, Lysenko MA (1988) Cryptic bryozoa, leeward fringing reef of Bonaire, Netherlands Antilles, and their paleoecological application. J Paleont 62:427-439

Kolodziej B (1997) Boring foraminifera from exotics of the Štramberk-type limestones (Tithonian-Lower Berriasian, Polish Carpathians). Ann Soc Geol Poloniae 67:249-256

Krajewski M (2010) Facies, microfacies and development of the Upper Jurassic-Lower Cretaceous of the Crimean carbonate platform from the Yalta and Ay-Petri massifs (Crimea Mountains, Southern Ukraine). Rozpr Monografie 217:5-253

Leinfelder RR (2001) Jurassic reef ecosystems. In: Stanley GD Jr (ed) The history and sedimentology of ancient reef systems. Kluwer, New York, pp 251-309

Leinfelder RR, Nose M, Schmid DU, Werner W (1993) Microbial crusts of the Late Jurassic: composition, palaeoecological significance and importance in reef construction. Facies 29:195-230

Littler MM (1980) Morphological form and photosynthetic performances of marine macroalgae: tests of a functional/form hypothesis. Bot Mar 22:161-165

Littler MM, Arnold KE (1982) Primary productivity of marine macroalgal functional-form groups from southwestern North America. J Phycol 18:307-311

Littler MM, Littler DS (1980) The evolution of thallus form and survival strategies in benthic marine macroalgae: field and laboratory tests of a functional form model. Am Nat 116:25-44

Littler MM, Littler DS (1983) Heteromorphic life-history strategies in the brown alga Scytosiphon lomentaria (Lyngb.) Link. J Phcyol 19:425-431

Littler MM, Littler DS, Taylor PR (1983) Evolutionary strategies in a tropical barrier reef system: functional-form groups of marine macroalgae. J Phycol 19:229-237

Logan A, Wirtz P, Swinnen F (2007) New record of Novocrania (Brachiopoda, Craniida) from Madeira, with notes on recent brachiopod occurrences in the Macaronesian archipelagos. Life Mar Sci 24:17-22

Lortie CJ, Aarssen LW (1996) The specialization hypothesis for phenotypic plasticity in plants. Int J Plant Sci 157:484-487

Lukeneder A, Harzhauser M (2003) Olcostephanus guebhardi as cryptic habitat for an Early Cretaceous coelobite community (Valanginian, Northern Calcareous Alps, Austria). Cretac Res 24:477-485

Meesters ER, Knijn P, Willemsen R, Pennartz R, Roebers G, Van Soest RWM (1991) Sub-rubble communities of Curaçao and Bonaire coral reefs. Coral Reefs 10:189-197

Moreno-Bedmar JA, Company M, Bover-Arnal T, Salas R, Delanoy G, Martínez R, Grauges A (2009) Biostratigraphic characterization by means of ammonoids of the lower Aptian Oceanic Anoxic Event (OAE1a) in the eastern Iberian Chain (Maestrat Basin, eastern Spain). Cretac Res 30:864-872

Moreno-Bedmar JA, Company M, Bover-Arnal T, Salas R, Delanoy G, Maurrasse FJ, Grauges A, Martínez R (2010) Lower Aptian ammonite biostratigraphy in the Maestrat Basin (Eastern Iberian Chain, Eastern Spain). A Tethyan transgressive record enhanced by synrift subsidence. Geol Acta 8:281-299

Morycowa E, Roniewicz E (1995) Microstructural disparity between Recent fungiine and Mesozoic microsolenine scleractinians. Acta Palaeont Polon 40:361-385

Nabivailo YV, Titlyanov EA (2006) Competitive relationships in natural and artificial algal communities. Russ J Mar Biol 32:521-531

Noffke N (2008) Turbulent lifestyle: microbial mats on Earth's sandy beaches-Today and 3 billion years ago. GSA Today 18, doi: 10.1130/GSATG7A.1 
Pachut JF, Cuffey RJ, Kobluk DR (1995) Depth-related associations of cryptic-habitat bryozoans from the leeward fringing reef of Bonaire, Netherland Antilles. Palaios 10:254-267

Padilla DK, Allen BJ (2000) Paradigm lost: reconsidering functional form and group hypotheses in marine ecology. J Exp Mar Biol Ecol 250:207-221

Pearcy RW, Muraoka H, Valladares F (2005) Crown architecture in sun and shade environments: assessing function and trade-offs with a three-dimensional simulation model. New Phytol 166:791-800

Rasmussen KA, Brett CE (1985) Taphonomy of Holocene cryptic biotas from St. Croix, Virgin Islands: Information loss and preservational biases. Geology 13:551-553

Rasser MW, Riegl B (2002) Holocene coral reef rubble and its binding agents. Coral Reefs 21:57-72

Reitner J, Engeser TS (1987) Skeletal structures and habitats of Recent and fossil Acanthochaetetes (subclass Tetractinomorpha, Demospongiae, Porifera). Coral Reefs 6:13-18

Reitner J, Thiel V, Zankl H, Michaelis W, Wörheide G, Gautret P (2000) Organic and biogeochemical patterns in cryptic microbialites. In: Riding R, Awramik SM (eds) Microbial sediments. Springer, Berlin, pp 149-160

Reolid M, Molina JM (2010) Serpulid-Frutexites assemblage from shadow-cryptic environments in Jurassic marine caves (Betic Cordillera, South Spain). Palaios 25:468-474

Richter C, Wunsch M (1999) Cavity-dwelling suspension feeders in coral-reefs: a new link in reef trophodynamics. Mar Ecol Prog Ser 188:105-116

Riding R (1991) Classification of microbial carbonates. In: Riding R (ed) Calcareous algae and stromatolites. Springer, Berlin, pp 21-51

Salas R, Casas A (1993) Mesozoic extensional tectonics, stratigraphy, and crustal evolution during the Alpine cycle of the eastern Iberian basin. Tectonophysics 228:33-55

Salas R, Guimerà J, Martín-Closas C, Meléndez A, Alonso A (2001) Evolution of the Mesozoic Central Iberian Rift System and its Cainozoic inversion (Iberian Chain). In: Ziegler PA, Cavazza W, Roberston AHF, Crasquin-Soleau S (eds) Peri-Tethys Memoir 6: Peri-Tethyan Rift/Wrench Basins and Passive Margins. Mém Mus Nat Hist Nat Paris, vol 186, pp 145-186

Salas R, García-Senz J, Guimerà J, Bover-Arnal T (2010) La apertura del Atlántico y la evolución de las cuencas de rifting intraplaca de Iberia durante el Jurásico Superior y el Cretácico Inferior. In: Ruiz-Omeñaca JI, Piñuela L, García-Ramos JC (eds) Comunicaciones del V Congreso del Jurásico de España, p. 134

Sambamurty AVSS (2005) A textbook of algae. IK Publisher, New Delhi

Schäfer P, Senowbari-Daryan B (1983) Die Kalkalgen aus der Obertrias von Hydra, Griechenland. Palaeontographica 185:83-142

Schlagintweit F (2010) Taxonomic revision of Lithocodium aggregatum Elliott sensu Schmid \& Leinfelder, 1996. Jb Geol BA 150:393-406

Schlagintweit F, Velić I (2011) Foraminiferan tests and dasycladalean thalli as cryptic microhabitats for thaumatoporellacean algae from Mesozoic (Late Triassic-Late Cretaceous) platform carbonates. Facies. doi:10.1007/s10347-010-0263-8

Schlagintweit F, Bover-Arnal T, Salas R (2010) Erratum to: New insights into Lithocodium aggregatum Elliott 1956 and Bacinella irregularis Radoičić 1959 (Late Jurassic-Lower Cretaceous): two ulvophycean green algae (?Order Ulotrichales) with a heteromorphic life cycle (epilithic/euendolithic). Facies 56:635673

Schlichting CD (1986) The evolution of phenotypic plasticity in plants. Ann Rev Ecol Syst 17:667-693

Schlichting CD, Levin DA (1984) Phenotypic plasticity of annual Phlox: tests of some hypotheses. Am J Bot 71:252-260

Schmid DU, Leinfelder RR (1996) The Jurassic Lithocodium aggregatum-Troglotella incrustans foraminiferal consortium. Palaeontology 39:21-52

Segonzac G, Marin P (1972) Lithocodium aggregatum Elliott et Bacinella irregularis Radoičić de l'Aptien de Teruel (Espagne): deux stades de croissance d'un seul et même organisme incertae sedis. Bull Soc Géol France (Série 7) 14:331-335

Steneck RS, Dethier MN (1994) A functional group approach to the structure of algal-dominated communities. Oikos 69:476-498

Tomás S, Aguirre J, Braga JC, Martín-Closas C (2007) Late Hauterivian coralline algae (Rhodophyta, Corallinales) from the Iberian Chain (E Spain). Taxonomy and the evolution of multisporangial reproductive structures. Facies 53:79-95

Tomás S, Löser H, Salas R (2008) Low-light and nutrient-rich coral assemblages in an Upper Aptian carbonate platform of the southern Maestrat Basin (Iberian Chain, eastern Spain). Cretac Res 29:509-534

Tucker ME, Wright VP (1990) Carbonate sedimentology. Blackwell Science, Oxford

Underwood AJ (2006) Why overgrowth of intertidal encrusting algae does not always cause competitive exclusion. J Exp Mar Biol Ecol 330:448-454

Vennin E, Aurell M (2001) Stratigraphie séquentielle de l'Aptien du sous-bassin de Galvé (Province de Teruel, NE de l'Espagne). Bull Soc Géol France 172:397-410

Wörheide G (1998) The reef cave dwelling ultraconservative coralline demosponge Astrosclera willeyana Lister 1900 from the Indo-Pacific. Micromorphology, ultrastructure, biocalcification, isotope record, taxonomy, biogeography, phylogeny. Facies 38:1-88

Yamamoto N, Kitamura A, Ohmori A, Morishima Y, Toyofuku T, Ohashi S (2009) Long-term changes in sediment type and cavernicolous bivalve assemblages in Daidokutsu submarine cave, Okinawa Islands: evidence from a new core extending over the past 7, 000 years. Coral Reefs 28:967-976

Zankl H (1993) The origin of high-Mg-Calcite microbialites in cryptic habitats of Caribbean coral reefs-their dependence on light and turbulence. Facies 29:55-60

Zuschin M, Mayrhofer S (2009) Brachiopods from cryptic coral reef habitats in the northern Red Sea. Facies 55:335-345 